\title{
Saharan dust-induced chlorophyll blooms in the north- west African Upwelling
}

\author{
Antonio G. RAMOS ${ }^{(1)}$, Emilio CUEVAS ${ }^{(2)}$, Carlos PÉREZ ${ }^{(3)}$, J.M. BALDASANO ${ }^{(3)}$ Josep \\ COCA $^{(1)}$, Alex REDONDO(1), Silvia ALONSO-PÉREZ ${ }^{(2)}$, Juan José BUSTOS ${ }^{(2)}$, Sergio \\ RODRIGUEZ ${ }^{(2)}$, Michel PETIT ${ }^{(4)}$, Slobodan NICKOVIC ${ }^{(5)}$
}

(1) SeaSnet Canarias. Dpto. de Biología (Univ. of Las Palmas de Gran Canaria).Campus de Tafira. 35017-Las Palmas G.C., Canary Islands, Spain. aramos@pesca.gi.ulpgc.es.

(2) Instituto Nacional de Meteorología. Centro de Investigación Atmosférica de Izaña c/La Marina, 20. 38071 - SC Tenerife. Canary Islands, Spain.

(3) Earth Sciences Department. Barcelona Supercomputing Center - Centro Nacional de Supercomputación.Edificio Nexus Il c/Jordi Girona 29, 08034-Barcelona, Spain.

(4) SEASnet Montpellier. Institut de Recherche pour le Développement (IRD). Maison de la Télédétection, 500 Rue JF Breton, 34093 Montpellier CEDEX 05, France.

(5) Atmospheric Research and Environment Programme. World Meteorological Organization. 7 bis, Avenue de la Paix. BP2300, 1211 Geneva 2. Switzerland.

\section{ABSTRACT}

During the period 2000-2005, the atmospheric dynamic showed a significant influence on the dust inputs dynamic and, as a result, on the primary production of the northwest African Upwelling System since 2000 to 2005. In this period, the annual mean sea level pressure became higher, ranging from 1014 to $1015 \mathrm{mb}$. Mean annual zonal wind intensity became higher (from 1.1 to $1.8 \mathrm{~m} \mathrm{~s}^{-1}$ ), while the mean annual meridional wind reduced from 6.2 to $5.3 \mathrm{~m} \mathrm{~s}^{-1}$. Mean annual satellite-derived AVHRR/NOAA Sea Surface Temperature recorded in the northwest African Upwelling becomes warmer with $18.3^{\circ} \mathrm{C}$ to $18.8^{\circ} \mathrm{C}$ in Cape Ghir, and from $19.5^{\circ} \mathrm{C}$ to $20.3^{\circ} \mathrm{C}$ north Canary Islands waters. Chlorophyll data from SeaWiFS/OV-2 showed a different pattern trend. Mean annual $\mathrm{CHL}$ levels increased at eutrophic-like waters of Cape Ghir from $0.65 \mathrm{mg} \mathrm{m}^{-3}$ to $0.9 \mathrm{mg} \mathrm{m}^{-}$. However, data were significantly reduced from $0.59 \mathrm{mg} \mathrm{m}^{-3}$ to $0.31 \mathrm{mg} \mathrm{m}^{-3}$ in oligotrophic-like waters of the Canary Islands. Changes observed in the role of $\mathrm{CHL}$ during the last 6-years period could be associated to intensive dust deposition and the exceptional weather warming observed in this area since 2000. However, it is addressed to a single 7 years period and conclusions on

Remote Sensing of Inland, Coastal, and Oceanic Waters, edited by Robert J. Frouin, Serge Andrefouet, Hiroshi Kawamura, Mervyn J. Lynch, Delu Pan, Trevor Platt,

Proc. of SPIE Vol. 7150, 715011 - (C) 2008 SPIE - CCC code: 0277-786X/08/\$18 - doi: 10.1117/12.804880 
possible links between dust deposition and marine biochemistry activity cannot be generalized.

\section{INTRODUCTION}

Photosynthesis in the ocean is the most important biochemical process of conversion of Inorganic Carbon (IC) into biomass (Organic Carbon, $O C$ ). The $O C$ generated through this primary production (photosynthetic) process is transferred to the higher trophic layer in superficial waters where most marine life develops. However, the excess of unused $C$ (rejected) undergoes a progressive sinking to the bottom. In the deep ocean layers, this rejected $O C$ can go through two processes: it is either recycled by the heterotrophic flora and transformed into reusable IC or it stays fixed as a sedimentary stratum at the bottom [Aristegui et al., 2003; Basterretxea G. and J. Arístegui, 2000]. This cycle, however, requires some additional nutrients in high concentrations, mainly Nitrogen ( $N$ ) and Phosphorus ( $P$ ). The availability (upwelling system) or non-availability (oligotrophic oceanic waters) of any of these macronutrient elements ( $N$ and $P$ ) depends on the vertical mixing supply to upper waters or by diazotrophic Nitrogen-fixing processes.

However, the absence of other available key nutrients such as Iron (Fe) and Manganese (N) can also limit the conversion of IC into OC. This micronutrients limitation is associated to its extremely low solubility (nanomolar levels) and are mostly supplied in the NE Atlantic by the exogenic dust deposition events [Prospero and Carlson, 1991; Lenes et al., 2001; Zeebe and Archer, 2005, Liu and Millero, 2005; Capone et al., 1997; Kremling and Streu, 1993]. Thus, long-term trend changes on the concentration of these trace elements would change the primary production role in both poor oligotrophic and rich eutrophic oceanic areas. In this paper, we focus in preliminar long-term trend of geophysical and meteorological indicators in the northwest African waters during the 
warmest 6-years period of the century (2000-2005), and how this changes influence the dust deposition input and, for instance, the primary production role in both areas.

\section{METHODOLOGY}

Meteorological parameters, satellite images data and model dust deposition inputs were collected from january 2000 to December 2006 over the northwest African waters at two stations located at Cape Ghir (upwelling station) and north Canary Island (Figure 1).

Wind components at $10 \mathrm{~m}$ height have been obtained from the European Centre for Medium-Range Weather Forecasts (ECMWF) T511 L60 operational analysis at 00, 06, 12 and 18 UTC. The Dust REgional Atmospheric model (DREAM) was designed to simulate and/or predict the atmospheric cycle of mineral dust aerosol [Pérez et al., 2006a, 2006b; Papayannis et al., 2007; Pérez et al., 2007]. The model incorporates advanced parameterizations of all the major phases of the atmospheric dust cycle, such as emission, diffusion, advection and deposition. All the model components are described in Nickovic et al. [2001]. Satellite-derived parameters were obtained during the event: Sea

Surface Temperature (SST) images were supplied by the Jet Propulsion Laboratory (JPL) PODAAC Pathfinder. Satellite-derived SeaWiFS/OV-2 chlorophyll-a (CHL) images were extracted from the NASA Ocean Colour Web. Data were projected on SMI cylindrical equidistant at different ground resolutions [Coca and Ramos, 2004].

\section{RESULTS AND DISCUSSION}

Mean sea level pressure, AVHRR/NOAA SST and wind components obtained from the ECMWF showed the warmest 7-years period reported since 1912. From 2000 to 2006, the annual mean sea level pressure becomes higher ranging from 1014 to $1015 \mathrm{mb}$. This change on the atmospheric circulation influenced the zonal and meridional wind components dynamic. Mean annual zonal wind intensity became higher during the 7-years period (from 
1.1 to $1.8 \mathrm{~m} \mathrm{~s}^{-1}$ ). However, the mean annual meridional wind becomes lower from 6.2 to $5.3 \mathrm{~m}$ $s^{-1}$ ) (shown in Figure 2).

The increase of the east-west component of the wind together a reduction of the north trade wind component would be translated into a change of the annual flux of Saharan dust over the northwest African Upwelling system. Annual average dry flux of Saharan dust can range from 0.03 to $0.08 \mathrm{~g} \mathrm{~m}^{-2} \mathrm{~d}^{-1}$ or $1.7 \times 10^{6}$ tons $\mathrm{yr}^{-1}$ as inferred from the experimental dry deposition (Torres et al., 2002). Our DREAM model derived data showed that at the north Canary Islands station, the annual dry dust deposition data reduced from $0.12 \mathrm{mg} \mathrm{m}^{-2}$ $\mathrm{d}^{-1}$ (2000) to $0.10 \mathrm{~g} \mathrm{~m}^{-2} \mathrm{~d}^{-1}$ (2006) north Canary Islands. However, in the Cape Ghir location station DREAM model derived data showed that annual dry dust deposition data increased from $0.025 \mathrm{mg} \mathrm{m}^{-2} \mathrm{~d}^{-1}$ (2000) to $0.040 \mathrm{mg} \mathrm{m}^{-2} \mathrm{~d}^{-1}$ (2006) (shown in Figure 3).

Mean annual satellite-derived AVHRR/NOAA SST recorded in the northwest African Upwelling becomes warmer. It ranged between $18.3^{\circ} \mathrm{C}(2000)$ to $18.8^{\circ} \mathrm{C}$ (2006) in the coastal eutrophic station located at Cape Ghir and from $19.5^{\circ} \mathrm{C}$ (2000) to $20.3^{\circ} \mathrm{C}$ (2006) in the oceanic oligotrophic station north Canary Islands waters (Figure 4a,b). Some authors [Ramos et al., 2005] revealed that in the canarian waters, the SST ranges between $17^{\circ} \mathrm{C}$ in winter to $24^{\circ} \mathrm{C}$ in summer. However, some areas at the south of the canarian waters presented SST peaks during this period (2004) of $28.5^{\circ} \mathrm{C}$, records never reported before.

Aristegui et al. [1997] and Basterretxea and Arístegui [2000] investigated the mean annual cycles of $\mathrm{CHL}$ in this area. The authors concluded that in the canarian oligrotrohic waters, values of mean annual $\mathrm{CHL}$ oscillated around $0.4 \mathrm{mg} \mathrm{m}^{-3}$. However, in the rich eutrophic upwelled waters of Cape Ghir the mean annual $\mathrm{CHL}$ levels arised to $0.8 \mathrm{mg} \mathrm{m}^{-3}$. As a result of the progressive increase of the SST observed in both Canary Island and Cape Ghir waters during 2000-2005, it could be expected a progressive reduction of the mean annual $\mathrm{CHL}$ concentration in both locations. Our CHL images from the SeaWiFS/OV-2 showed a different pattern trend. Mean annual CHL levels increased (like dry dust deposition) at Cape Ghir from $0.65 \mathrm{mg} \mathrm{m}^{-3}$ (2000) to $0.9 \mathrm{mg} \mathrm{m}^{-3}$ (2006) indicating a process of progressive 
eutrophization on the upwelling sector. However, in the Canary Islands waters the mean annual CHL levels becomes significantly reduced from $0.59 \mathrm{mg} \mathrm{m}^{-3}$ (2000) to $0.31 \mathrm{mg} \mathrm{m}^{-3}$ (2006) (like dry dust deposition), indicating a process of progressive tropical-like ocean landscape (Figure 5a,b).

Annual fluxes changes of Saharan dust could produce a significant impact on the bigeochemical cycle of trace elements, providing a source of nutrients required for $\mathrm{N}_{2}$ fixing diazotrophic cyanobacterial growth [Capone et al., 1997; Lenes et al., 2001]. Thus, Ramos et al., [2005] reported in 2004 the development of an extensive and inedit bloom of the diazotrophic cyanobacterium Trichodesmium erythraeum Ehrenberg in the northwest African Upwelling never described before [Hood et al., 2002]. The early stages of this anomalous diazotrophic event and its possible relationship to episodic Saharan dust deposition may represent the dominant source of these new $\mathrm{CHL}$ pool observed in the Upwelling System location. However, in oceanic oligotrophic waters the reduction of the dust fluxes observed in this work could generate a significant reduction of the $\mathrm{CHL}$ levels and as a direct consequence, this sector would become poorer.

\section{BIBLIOGRAPHY}

- Arístegui, J, P. Tett, A. Hernández-Guerra, G. Basterretxea, M.F. Montero, K. Wild, P. Sangrá, S. Hernández-León, M. Cantón, J.A. García - Braun, M. Pacheco and E.D. Barton, "The influence of island-generated eddies on chlorophyll distribution: a study of mesoscale variation around Gran Canaria". Deep-Sea Research, 44, 71-96 (1997).

- Basterretxea G. and J. Arístegui, "Mesoscale variability in phytoplankton biomass distribution and photosynthetic parameters in the Canary-NW African coast transition zone". Marine Ecology Progress Series, 197, 27-40 (2000).

- Coca, J. and A. Ramos, "Relationships between satellite-derived oceanic events and the albacore tuna (Thunnus alalunga, Bonaterre, 1788) artisanal fishing grounds in the NE 
Atlantic". In Remote Sensing of the Ocean and Sea Ice (Ed. C. Bostater Jr. and Rosalia Santoreli). Proceedings of the SPIE, 5569, 116-129 (2004).

- Hood, R.R., Subramaniam, A., May, L.R., Carpenter, E.J. and Capone, D.G., "Remote sensing of nitrogen fixation by Trichodesmium". Deep-Sea Research II, 49, 23-147 (2002).

- Kremling K. and P. Streu, "Saharan dust influenced trace elements fluxes in deep North Atlantic subtropical waters", Deep Sea Research, Part I, 40, 1155-1168 (1993).

- Lenes, J., Darrow, B., Cattrall, C., Heil, C. A., Callahan, M., Vargo, G., Byrne. R., Prospero J., Bates, D., Fanning, K. and Walsh, J. "Iron fertilization and the Trichodesmium response on the West Florida shelf". Limnology and Oceanography 46, 1261-1277, (2001).

- Liu, X.and F.J. Millero "The solubility of iron in seawater", Marine Chemistry, 77, 43-54, (2005).

- Nickovic, S., G. Kallos, A. Papadopoulos, and O. Kakaliagou, "A model for prediction of desert dust cycle in the atmosphere". Journal of Geophysical Research, 106, D16, 1811318129, (2001).

- Papayannis, A., H. Q. Zhang, V. Amiridis, H. B. Ju, G. Chourdakis, G. Georgoussis, C. Pérez, H. B. Chen, P. Goloub, R. E. Mamouri, S. Kazadzis, D. Paronis, G. Tsaknakis, and J. M. Baldasano (2007), "Extraordinary dust event over Beijing, China, during April 2006: Lidar, Sun photometric, satellite observations and model validation". Geophysical Research Letters, 34, L07806, doi:10.1029/2006GL029125 (2007).

- Pérez, C., S. Nickovic, J. M. Baldasano, M. Sicard, F. Rocadenbosch, and V. E. Cachorro, "A long Saharan dust event over the western Mediterranean: Lidar, Sun photometer observations, and regional dust modelling". Journal of Geophysical Research, 111, D15214, doi:10.1029/2005JD006579 (2006a). 
- Pérez, C., S. Nickovic, G. Pejanovic, J. M. Baldasano, and E. Özsoy, "Interactive dust radiation modelling: A step to improve weather forecasts". Journal of Geophysical Research, 111, D16206, doi:10.1029/2005JD006717 (2006b).

- Pérez, C., Jiménez-Guerrero, P., Jorba, O., Baldasano, J.M., Cuevas, E., Nickovic, S., Querol, X., "Long-term simulations (1958-2006) of Saharan dust over the Mediterranean and the Eastern North Atlantic with the DREAM regional dust model". In: XXIV International Union of Geodesy and Geophysics (IUGG) General Assembly, Perugia, Italy, 213 (2007).

- Prospero, J. M. and T. N. Carlson, "Saharan air outbreaks over the tropical North Atlantic". Pure and Applied Geophysics 119 (3), 677-691, (1981).

- Ramos A., A. Martel, G. Codd, E. Soler, J. Coca, A. Redondo, L. Morrison, J.Metcalf, A. Ojeda, Sonia Suárez and M. Petit, "Bloom of the marine diazotrophic cyanobacterium Trichodesmium erythraeum Ehrenberg in the Northwest African Upwelling". Marine Ecology Progress Series, 301, 303-305, (2005).

- Torres, M., M. Gelado, C. Collado, V. Siruela, P. Cardona and J. Hernández-Brito, "Variability of dust inputs to the CANIGO zone". Deep-Sea Research II, 49, 3455-3464.

- Utermohl H. "Zur Vervollkommung der quantitative Phytoplankton-Methodik. Mitteilungen der Internationale Vereinigung fur theorietische und angewandte". Limnologie, 9, 1-38, (1958).

\section{FIGURES}




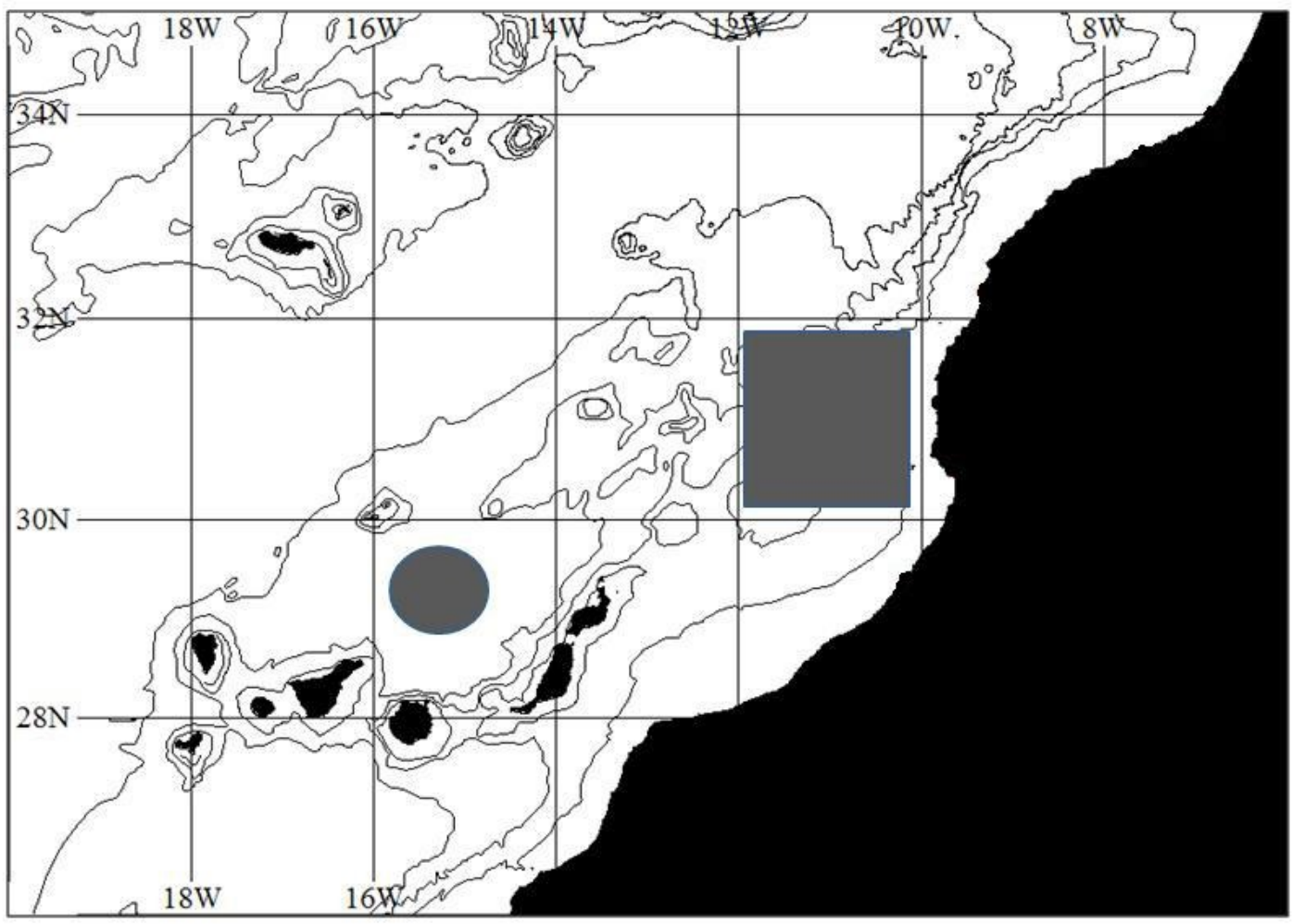

Figure 1. The northwest African Upwelling area. Data sets of dust deposition, SST and CHL were extracted from oligotrophic waters located to the north of the Canary Islands (circle box) from upwelled waters located off Cape Ghir (square box). 


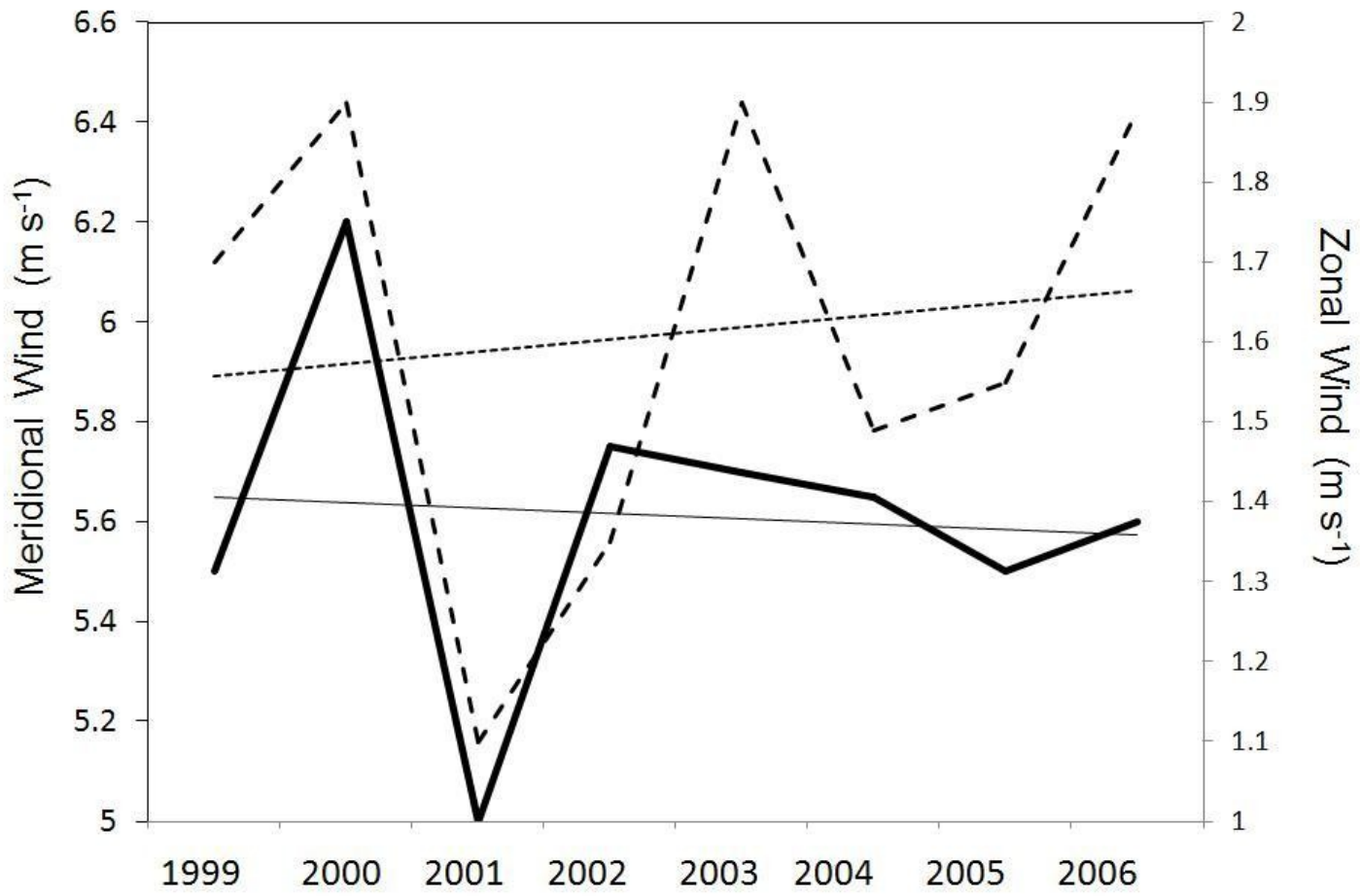

Figure 2. Annual mean meridional (solid line) and zonal (dashed line) wind speed series in the Northwest African Upwelling area from 1999 to 2006.

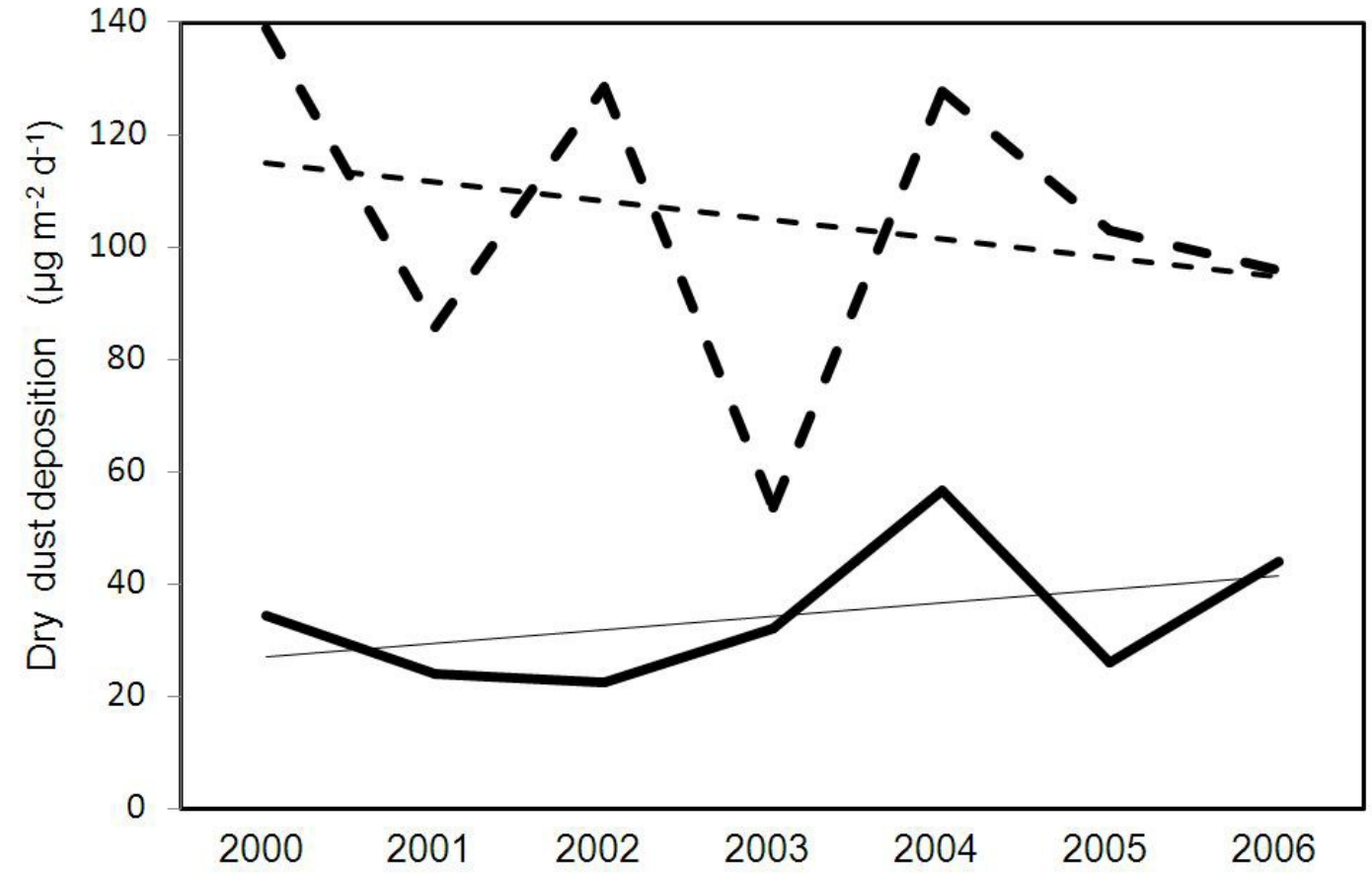

Figure 3. Annual mean DREAM-modelled dry dust deposition at Cape Ghir (solid line) and north of the Canary Islands (dashed line) from 2000 to 2006. 


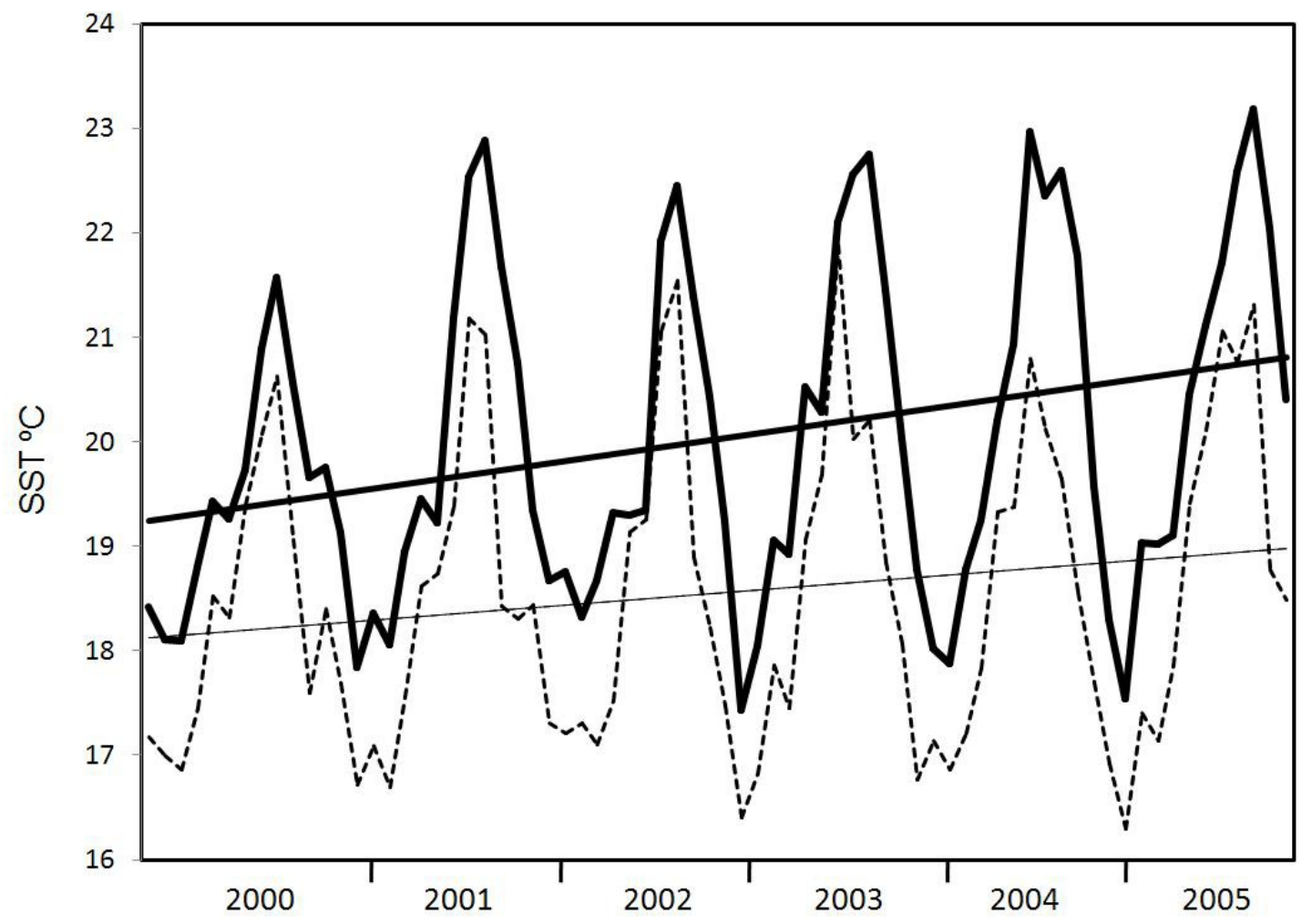

Figure 4a. Annual mean satellite-derived AVHRR/NOAA SST data series at Cape Ghir (dashed line) and north of the Canary Islands (solid line) from 2000 to 2005. 


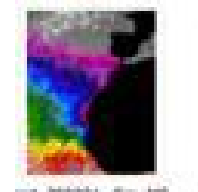

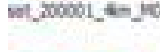

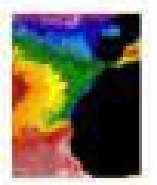

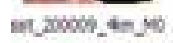

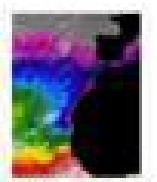

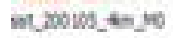

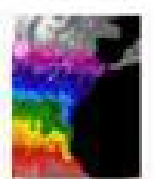

an 200201 in 10

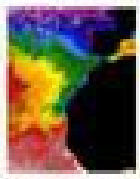

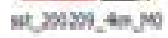

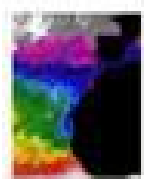

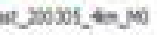

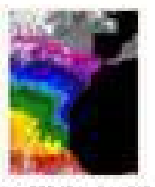

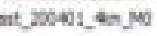

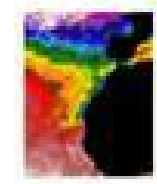

at $200409,4=00$

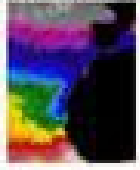

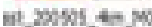
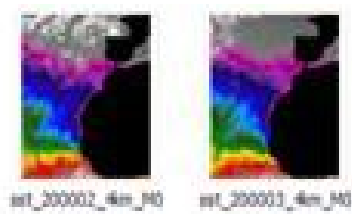

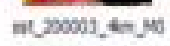

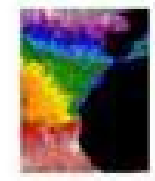

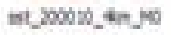
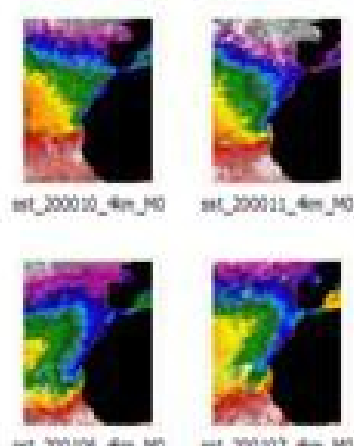

m( $20032,4=90$

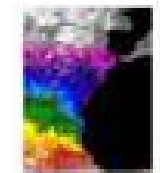

ist 200302 in 100

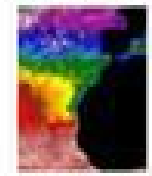

myocrilstaye

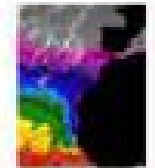

st $200203.6 \mathrm{sen}$

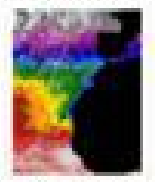

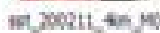

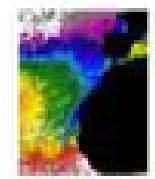

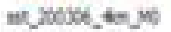

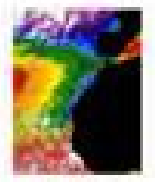

an $200009+4=y 0$

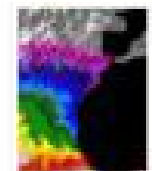

int, 2006e2,40 yo

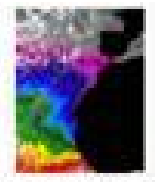

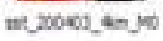

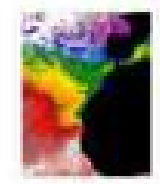

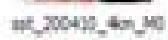

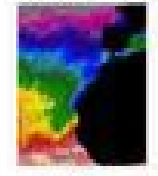

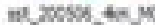

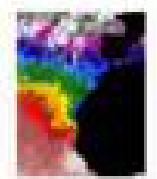

nt $200011,40 y=$

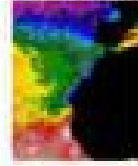

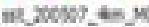

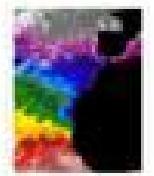

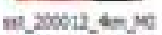

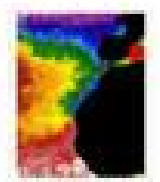

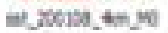

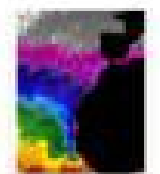

et 200xt in we

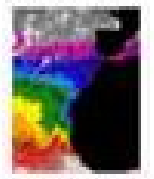

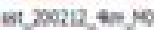

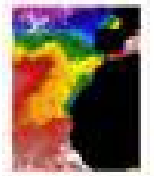

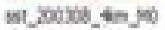

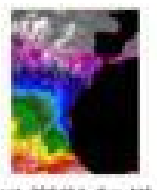

int 30000 , an jo

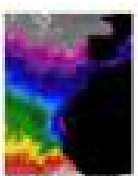

mintaoces_anjer

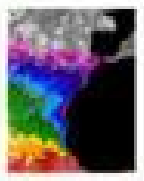

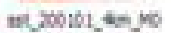

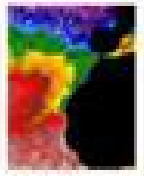

m $300100,40.50$

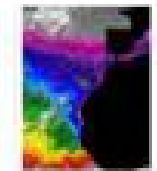

ast 200025 son vis

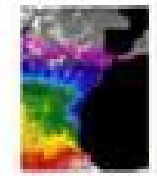

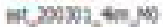

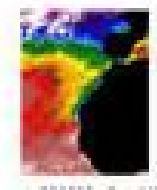

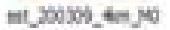

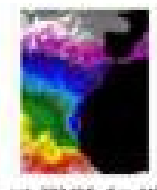

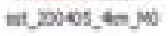

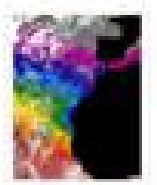

int 20045 4n

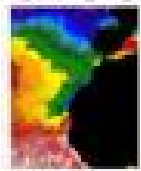

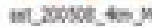

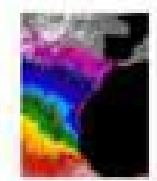

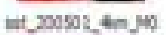

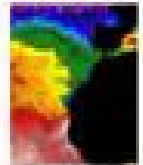

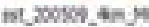

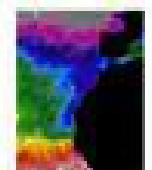

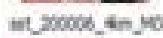

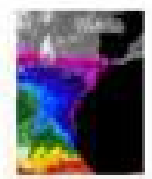

int $2000102,4=09$

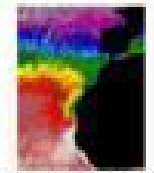

II)

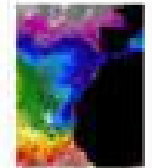

st zotas on 10

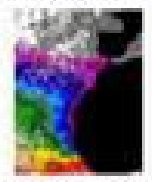

nit $20002,40, y 0$

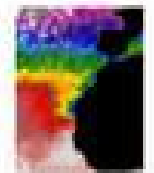

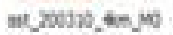
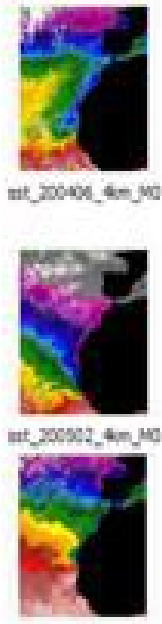
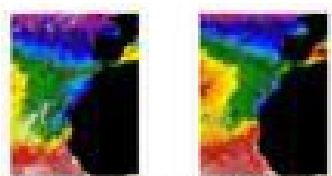

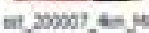

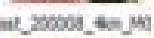
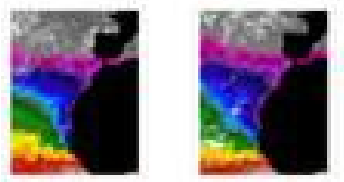

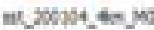
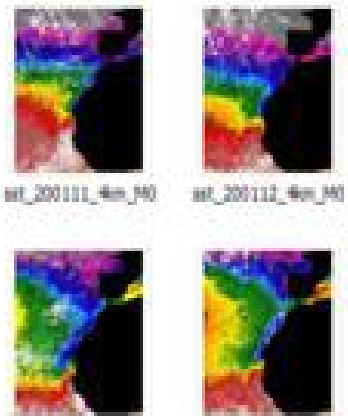

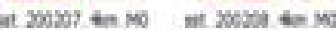
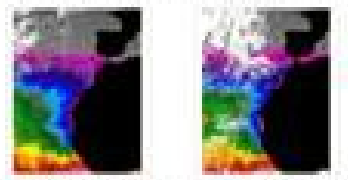

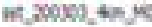

ist.20000, 40.40
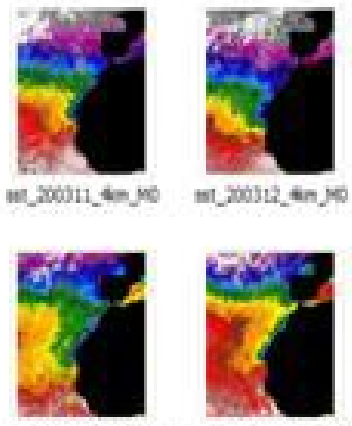

int,200et_tun jet

$\operatorname{sit} 200000$ _4 400
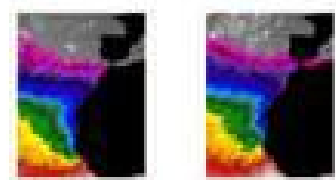

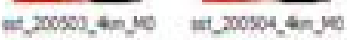
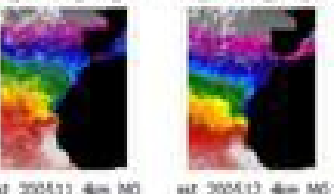

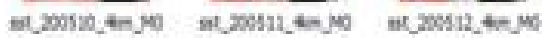

Figure 4b. Monthly mean satellite-derived AVHRR/NOAA SST images series in the NE African upwelling system from 2000 to 2005. 


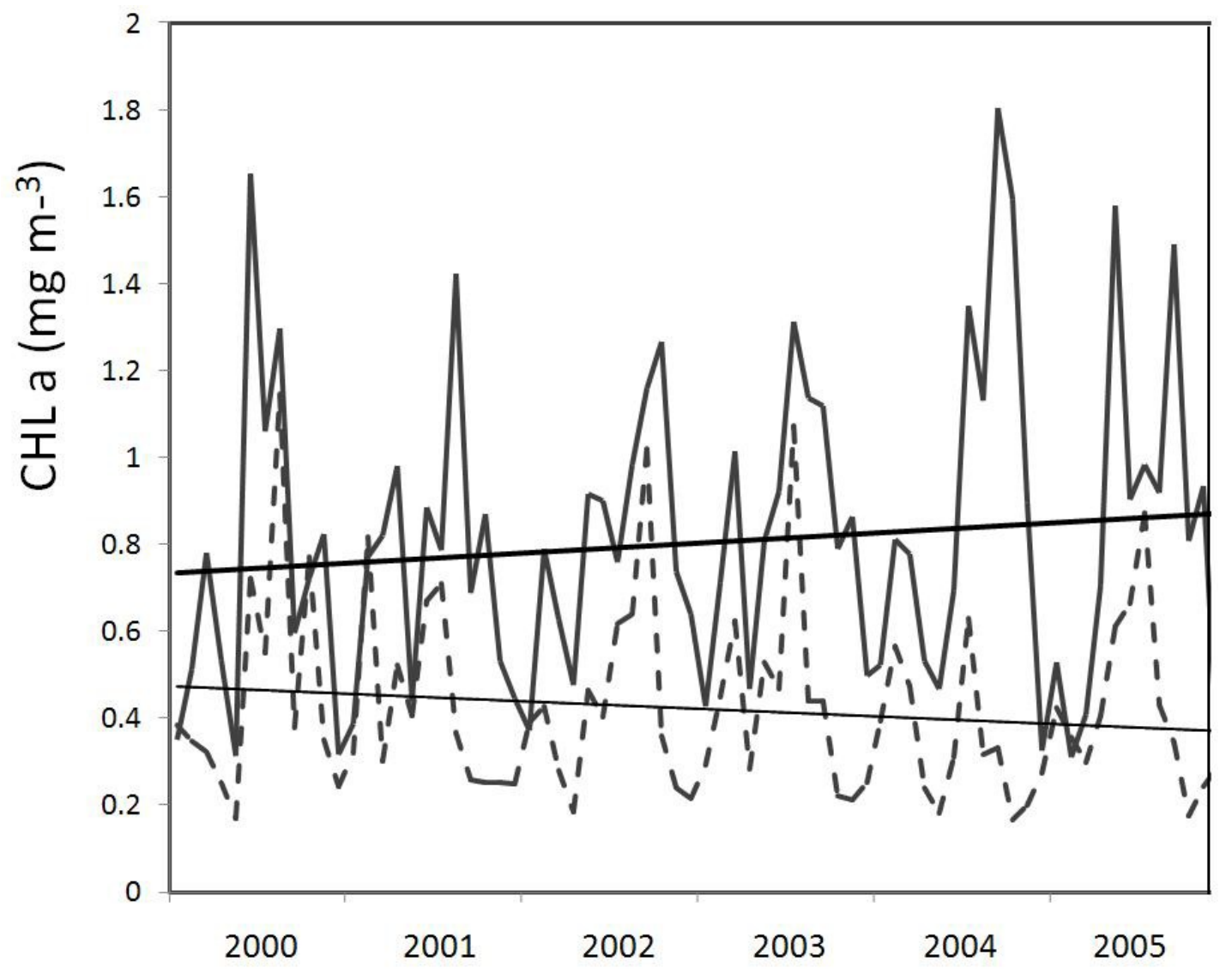

Figure 5a. Annual mean satellite-derived SeaWiFS/OV-2 CHL data series obtained at Cape Ghir (solid line) and north of the Canary Islands (dashed line) in the Northwest African Upwelling area from 2000 to 2005. 


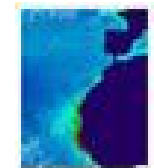

2x, 200001, knon y

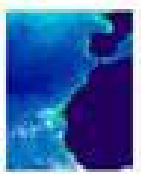

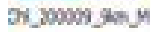

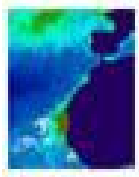

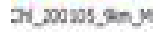

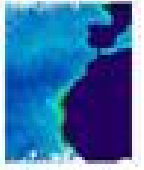

Fo 200301 sin y

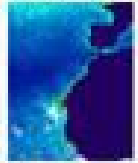

Or, 200000 , $/ 4 n$

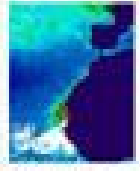

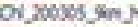

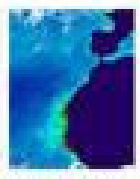

Or_trowisone.

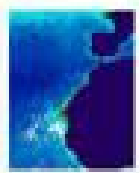

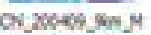

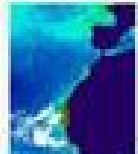

W. Wosus .90

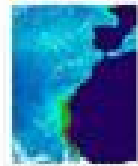

or $200002, \mathrm{kn}, \mathrm{y}$

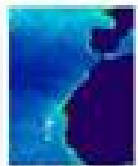

OL.300010 צres

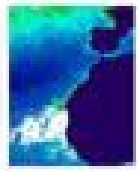

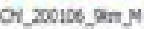

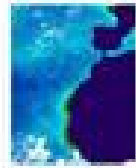

Or 200002 9is $\mathrm{N}$

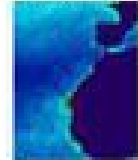

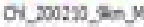

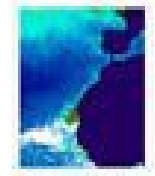

or reoses sen $y$

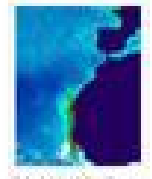

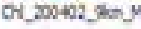

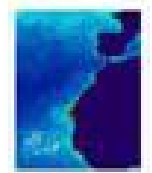

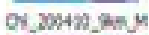

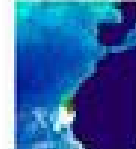

ov 200906 son $y$

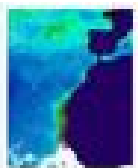

of 200003 sen y

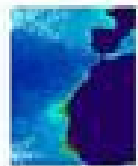

Or zoositshen $y$

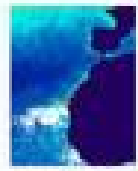

Cor 200207 . $30 \mathrm{x}$.

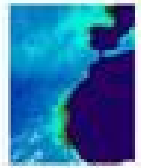

or 30000 son $x$

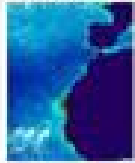

or $200211.9 \mathrm{~mm}$

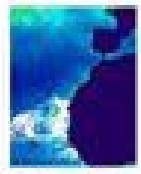

or $200007,900, y$
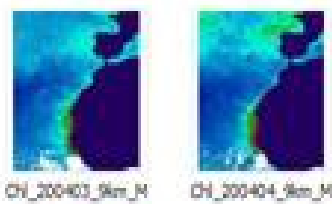

어 300404 \%

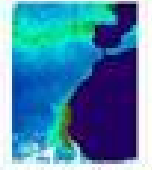

or $20000+9 \mathrm{sen}$

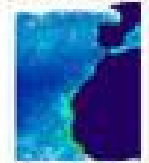

어, $200212,9=x$

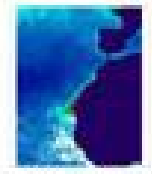

ON 300900 sin s.

Or_200000 on $N$
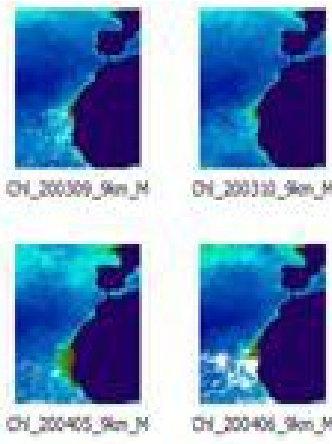

Dr_.200406 sting y
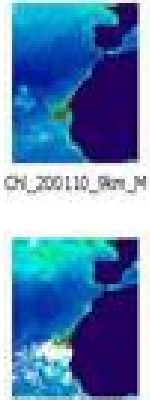

OC. $30006.96 \mathrm{~m}$

Or. overs she

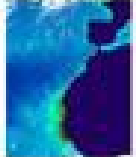

Or 200001, $9 \mathrm{~m}$

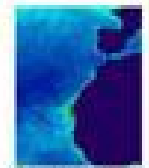

Or 20092 sin $y$

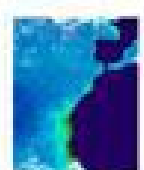

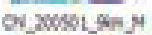

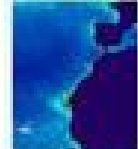

or 200509 \%

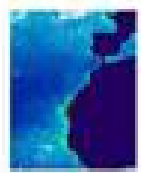

ON_zotityen $y$

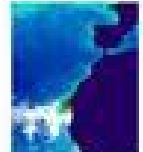

ov 200507 \%in $x$

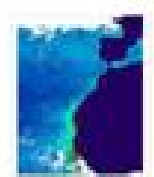

ON $200+12, y=y$
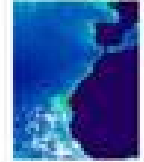

or xoses gis

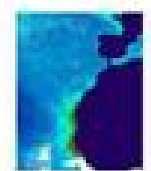

Or $320502,90 \mathrm{y}$

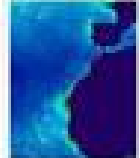

Or Yosit $9=$ or $3000 \mathrm{tit}, \mathrm{men}$

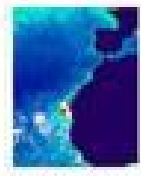

ON_200en_sen. $\mathrm{M}$

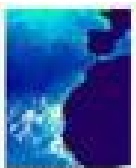

or 200007 ston $y$
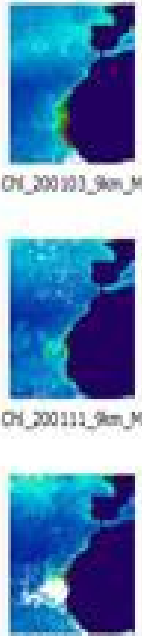

ON 30037 sin 4

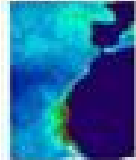

Or. 200003 . Pon $M$
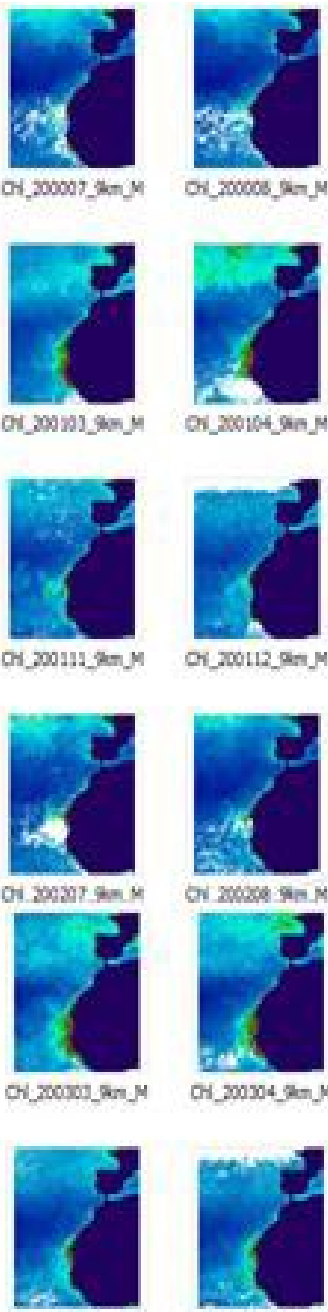

or 200000 sin $y$

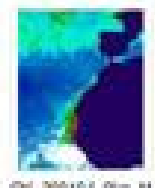

or axolotyey
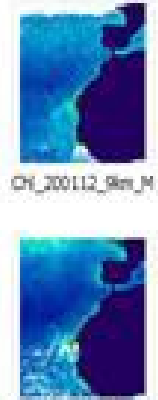

or zooge sin $\mathrm{x}$

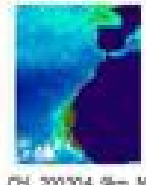

어 $300004 \% \mathrm{~km}$

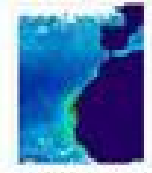

ov $x 00312,4=y$
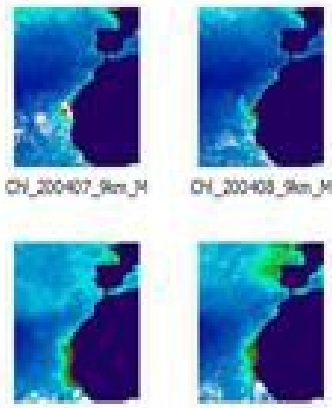

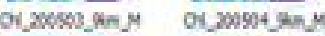
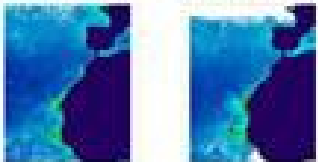

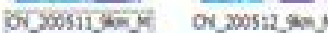

Figure 5b. Monthly mean satellite-derived SeaWiFS/OV-2 CHL images series obtained in the Northwest African Upwelling area from 2000 to 2005. 